\title{
Kadar mRNA Hypoxia Inducible Factor Alpha Plasma Darah Pasien Kanker Ovarium Tipe Mucinous Dan Serous
}

\author{
Siti Nur Chasanah, ${ }^{1}$ Teguh Aryandono, ${ }^{2}$ Sofia Mubarika Haryana ${ }^{3}$ \\ 1Departemen Biokimia dan biologi sel molekuler, Fakultas Kedokteran Universitas Wahid Hasyim, \\ ${ }^{2}$ Bagian Bedah, Fakultas Kedokteran, Universitas Gadjah Mada, Yogyakarta, Indonesia. \\ ${ }^{3}$ Bagian Histologi dan Biologi Molekular, Fakultas Kedokteran, Universitas Gadjah Mada, Yogyakarta, \\ Indonesia. \\ Email: sitinurchasanah@unwahas.ac.id
}

\begin{abstract}
Abstrak
Proses karsinogenesis pada kanker ovarium melibatkan regulasi tingkat molekular, salah satunya adalah mRNA. Beberapa penelitian sebelumnya menyebutkan bahwa disregulasi mRNA HIF1A terjadi pada berbagai kanker. Penelitian melaporkan adanya peningkatan ekspresi mRNA HIF1A pada kanker ovarium. Kanker sering berada dalam kondisi hipoksia, mRNA HIF1A merupakan regulator gen pada kondisi hipoksia. HIF1A terlibat dalam berbagai hallmark kanker. Berdasarkan hal tersebut, penelitian ini dilakukan untuk mengetahui apakah terdapat perbedaan ekspresi mRNA HIF1A pada plasma penderita kanker ovarium tipe mucinous dan serous. Sampel plasma diambil dari pasien kanker ovarium di RSUP Dr. Sardjito, tipe mucinous sebanyak 9 sampel dan tipe serous sebanyak 9 sampel. Total RNA diisolasi dari sampel plasma darah pasien kanker ovarium dengan menggunakan miRCURY RNA isolation Kit-Biofluid. Kuantifikasi mRNA HIF1A dilakukan One-step qRT-PCR dengan kit KAPA TM SYBR $^{\circledR}$. Hasil qRT-PCR dianalisis dengan menggunakan Biorad CFX Manager ${ }^{T M}$ Software. Hasil analisis menunjukkan bahwa terdapat perbedaan ekspresi mRNA HIF1A pada tipe serous dibandingkan dengan tipe mucinous ( $p$ value $=0,018$ ). Ekspresi mRNA HIF1A pada tipe serous meningkat 5,62 kali lipat dibandingkan dengan tipe mucinous. Penelitian ini telah berhasil membuktikan bahwa mRNA HIF1A lebih tinggi pada kanker ovarium tipe serous.
\end{abstract}

Kata kunci: Plasma, mRNA HIF1A, Serous, Mucinous

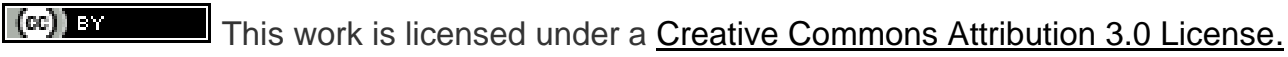

\section{PENDAHULUAN}

Pada tahun 2018 Indonesia menempati urutan ke-8 negara dengan kasus kematian tertinggi akibat kanker. Indonesia menempati urutan ke-5 kasus kematian akibat kanker ovarium. Kanker ovarium adalah salah satu keganasan ginekologis yang masih menjadi permasalahan kesehatan di seluruh dunia. Pada tahun 2018, kanker ovarium merupakan kanker dengan tingkat insidensi berada di urutan ke-10 paling banyak diderita.
Pada wanita insidensi berada pada urutan ke-8. Kanker ovarium berada di urutan ke-7 penyebab kematian karena kanker, urutan ke-7 penyebab kematian karena kanker pada wanita dan menempati pada urutan ke-7 prevalensi terbanyak pada wanita. ${ }^{[1,2,3]}$

Tingkat mortalitas yang tinggi disebabkan karena banyak pasien terdiagnosis sudah dalam keadaan stadium lanjut dan lebih dari $50 \%$ pasien dengan tingkat keganasan stadium lanjut akan berakhir pada 
kematian. Saat ini penyakit kanker ovarium masih menjadi masalah serius dalam kaitannya dengan manajemen klinik. Belum adanya metode deteksi dini yang memuaskan menyebabkan sulit dalam mendiagnosis dini. Sekitar $70-80 \%$ kasus baru kanker ovarium terdiagnosis pada stadium lanjut dan telah bermetastasis jauh. ${ }^{[4]}$ Pasien yang didiagnosis pada stadium lanjut (stadium FIGO III dan IV) kurang dari $45 \%$ yang memiliki harapan hidup sampai 5 tahun. ${ }^{[5,6]}$ Kondisi Hipoksia menyebabkan tumor memperoleh karakteristik menjadi agresif dan berpotensi meningkatkan metastasis, penurunan sensitivitas obat, penurunan apoptosis terkait p53, peningkatan instabilitas genetik dan laju mutasi. ${ }^{[7]}$ Salah satu efektor utama dari hipoksia adalah transcription factor HIF1A yang bertanggung jawab untuk meregulasi survival, angiogenesis dan pengalihan jalur metabolisme energi menjadi glikolisis (Warburg effect). HIF1A adalah regulator kunci dari transkripsional respon terhadap kondisi hipoksia. Aktivasi HIF1A menyebabkan ekspresi dari target gen HIF, yaitu beberapa gen yang terlibat dalam proses angiogenesis, metastasis, warburg effect dan survival. ${ }^{[8]}$ Terkait dengan hal tersebut perlu dilakukan penelitian untuk mengetahui ekspresi mRNA HIF1A pada kanker ovarium tipe mucinous dan serous.

\section{METODE PENELITIAN}

Sampel plasma darah dikoleksi dari pasien kanker ovarium di RSUP Dr. Sardjito dengan total 9 sampel plasma darah pasien kanker ovarium tipe mucinous dan 9 sampel plasma darah pasien kanker ovarium tipe serous. Isolasi RNA total menggunakan kit miRCURY $Y^{T M}$ RNA Isolation Kit-
Biofluids dari Exiqon sesuai dengan protokol. Sintesis cDNA menggunakan kit Universal cDNA synthesis kit (\#203300, Exiqon) sesuai dengan protokol. Ekspresi mRNA HIF1A dideteksi menggunakan real time PCR. Sekuens primer mRNA HIF1A yaitu: F: 5'AATGCTCCCCTCACCCAACG3'; R: 5'GCAGGGTCAGCA CTACTTCG3'. Sekuens primer mRNA Beta actin yaitu: F:5'GGGAATTCAAAACTGGAACGGT GAAGG3';R:5'GGAAGCTTATCAAAGT CCTCGG CCACA3'. Ekspresi mRNA HIF1A dikuantifikasi menggunakan kit KAPA SYBR FAST master mix kit. Data dianalisis dengan menggunakan Biorad CFX Manager ${ }^{\mathrm{TM}}$ Software untuk menghitung quantification cycle dari qPCR. Untuk menghitung perubahan relatif (fold change) pada ekspresi mRNA HIF1A hasil RT qPCR digunakan metode Livak. Uji komparatif menggunakan Independent Sample Ttest.

\section{HASIL}

Penggunaan metode one-step qRT-PCR dilakukan untuk memperoleh produk mRNA yang baik. Sampel hasil isolasi RNA langsung dilakukan qRTPCR tanpa melalui tahap sintesis cDNA secara terpisah sebelumnya. Proses qRT-PCR yang telah dilakukan berhasil mendeteksi adanya amplifikasi mRNA HIF1A dan mRNA $\beta$-Actin pada sampel plasma pasien kanker ovarium tipe mucinous dan serous. Nilai $\mathrm{Cq}$ hasil amplifikasi mRNA HIF1A dan mRNA $\beta$ Actin dapat digunakan untuk menghitung nilai ekspresi relatif dari mRNA HIF1A. Penghitungan nilai ekspresi relatif dari mRNA HIF1A dilakukan dengan cara menghitung nilai delta $\mathrm{Cq}$ antara mRNA HIF1A dan mRNA $\beta$-Actin. Hasil dari penghitungan nilai delta $\mathrm{Cq}$ tersebut disebut sebagai 
ekspresi relatif mRNA HIF1A.Nilai rerata ekspresi relatif dari mRNA HIF1A masing-masing kelompok ditampilkan pada Gambar 1.

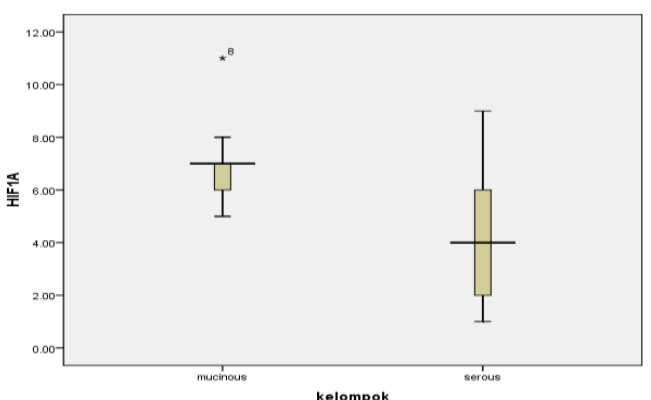

Gambar 1. Rerata Ekspresi Relatif Hasil qRT-PCR mRNA HIF1A pada Sampel Plasma Kanker Ovarium Tipe Mucinous dan Tipe Serous yang Dianalisis dengan Biorad CFX Manager ${ }^{T M}$ Software.

Hasil uji statistik komparatif Independent Sample t-test mRNA HIF1A ditunjukkan pada Tabel 1.

Tabel 1. Uji Stasistik Komparatif Data Kuantifikasi Ekspresi mRNA HIF1A Plasma Pasien Kanker Ovarium Tipe Mucinous dan Serous

\begin{tabular}{|c|c|c|c|c|}
\hline Variabel & & Mean & & $p$ value \\
\hline \multirow{3}{*}{$\begin{array}{l}\text { mRNA } \\
\text { HIF1A }\end{array}$} & Mucino & 7,60 & \pm & \\
\hline & us & 2,07 & & 18 * \\
\hline & Serous & $\begin{array}{l}4,68 \\
2,50\end{array}$ & \pm & \\
\hline
\end{tabular}

Berdasarkan hasil uji statistik komparatif didapatkan bahwa terdapat perbedaan ekspresi mRNA HIF1A pada tipe mucinous dibandingkan dengan tipe serous $(p<0,018)^{*}$.

Untuk mengetahui besar fold change mRNA HIF1A dari kelompok mucinous dan serous maka diperlukan nilai $\Delta \Delta \mathrm{Cq}$ mRNA HIF1A. Besar fold change dihitung dengan metode Livak Fold change $=2^{-\Delta \Delta \mathrm{Cq}}$, hasilnya dapat dilihat pada Tabel 2.
Tabel 2. Fold Change mRNA HIF1A pada Sampel Plasma Kanker Ovarium Tipe Mucinous dan Tipe Serous.

\begin{tabular}{|c|c|c|c|c|c|}
\hline Kelompok & Target & $\begin{array}{l}\text { Mean } \\
(\Delta \text { Cq) } \quad \pm \\
\text { Standar } \\
\text { deviasi }\end{array}$ & $\begin{array}{l}\Delta \Delta \mathbf{C} \\
\mathbf{q}\end{array}$ & $\begin{array}{l}\text { Fold } \\
\text { chang } \\
e \\
\left(2^{-\Delta \Delta C q}\right)\end{array}$ & $\begin{array}{l}\text { Fold } \\
\text { chan } \\
\text { ge } \\
-1 / 2 \\
\Delta \Delta \mathrm{q}\end{array}$ \\
\hline \multirow[t]{4}{*}{ Mucinous } & mRNA & 7,60 & & & \\
\hline & HIF1A & 2,07 & & & \\
\hline & mRNA & & - & & \\
\hline & $\beta$-Actin & & 2,4 & 5,62 & \\
\hline \multirow[t]{4}{*}{ Serous } & mRNA & 4,68 & 9 & & \\
\hline & HIF1A & 2,50 & & & \\
\hline & mRNA & & & & \\
\hline & $\beta$-Actin & & & & \\
\hline
\end{tabular}

Nilai fold change mRNA HIF1A sebesar 5,62 menunjukkan bahwa ekspresi mRNA HIF1A plasma tipe serous meningkat 5,62 kali lipat dibandingkan dengan tipe mucinous.

\section{DISKUSI}

Metode qRT-PCR dengan segala keunggulannya merupakan metode yang tepat untuk kuantifikasi ekspresi gen terutama mRNA. ${ }^{[9]}$ Molekul mRNA memiliki peran sebagai mesenger untuk translasi RNA menjadi sebuah protein. ${ }^{[10]}$ mRNA $\beta$-actin digunakan sebagai reference gene karena diekspresikan secara stabil tanpa terpengaruh keadaan patologis kanker pada kontrol sehat, kanker stadium awal maupun stadium lanjut, selain itu juga dapat ditemukan dalam

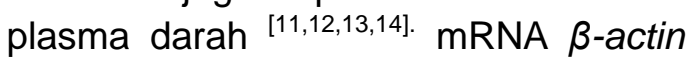
merupakan salah satu mRNA yang paling sering ditemukan pada plasma sehingga dapat digunakan sebagai endogenous control ${ }^{[15] \text {. }}$

Hasil penelitian menunjukkan bahwa ekspresi mRNA HIF1A sampel plasma tipe serous lebih tinggi dibandingkan dengan sampel plasma tipe mucinous. Perhitungan dengan metode Livak menunjukkan adanya peningkatan ekspresi mRNA HIF1A 
yang signifikan pada plasma pasien kanker ovarium tipe serous sebanyak 5,62 kali lipat dibandingkan dengan tipe mucinous. Ekspresi mRNA HIF1A berkaitan dengan stadium klinik dan overall survival yang buruk pada beberapa tipe kanker. $^{[16]}$ Upregulasi ekspresi mRNA HIF1A pada kanker tipe serous berkaitan dengan migrasi, adhesi, invasi dan metastasis dari sel kanker. ${ }^{[17,18]}$ mRNA HIF1A terlibat dalam berbagai jenis kanker yang berbeda. Ekspresi mRNA HIF1A dilaporkan sangat tinggi pada jenis kanker otak, kanker paru-paru, dan kanker payudara. Pada jenis kankerkanker tersebut mRNA HIF1A berfungsi sebagai oncogen. Tingkat ekspresi mRNA HIF1A yang tinggi juga dapat terjadi karena upregulate pada jalur biogenesis mRNA. Pada kasus kanker protein-protein supresor mengalami mutasi sehingga menyebabkan pembatasan ekspresi mRNA tidak berjalan dengan baik, hal ini menyebabkan ekspresi mRNA tinggi. ${ }^{[19,20,21,22]}$ Selain itu juga bisa di sebabkan karena rendahnya ekspresi mikroRNA akibat adanya mutasi pada kromosom. MikroRNA merupakan regulator posttranskripsi mRNA. Faktor transkripsi yang meningkat atau mengalami mutasi pada kasus kanker dapat mengakibatkan peningkatan ekspresi mRNA. ${ }^{[23]}$ Regulasi epigenetik, defect transkripsi dan biogenesis mRNA HIF1A tersebut mungkin merupakan beberapa penyebab terjadinya upregulate 5,62 kali lipat pada kanker ovarium tipe serous.

Perhitungan dengan metode Livak menunjukkan hasil peningkatan ekspresi (upregulated) mRNA HIF1A yang signfikan pada plasma pasien kanker ovarium tipe serous dibandingkan dengan tipe mucinous.
Ekspresi mRNA HIF1A berkaitan dengan clinical outcome yang buruk, indikator prognostik yang negatif, ukuran tumor, stadium, histopatologi dan grade. Hasil penelitian ini menunjukkan ekspresi mRNA HIF1A meningkat sebesar 5,62 kali pada plasma kanker ovarium serous dibandingkan dengan mucinous. Hasil penelitian sesuai dengan penelitian sebelumnya yaitu bahwa ekspresi HIF1A secara signifikan lebih tinggi pada kanker ovarium tipe serous dibandingkan mucinous. Selain itu tingkat ekspresi pada poorly differentiated carcinoma secara signifikan lebih tinggi dibandingkan pada well differentiated carcinoma ${ }^{[24]}$.

Peningkatan ekspresi mRNA HIF1A mungkin juga dapat disebabkan oleh rendahnya ekspresi protein tumor supressor PTEN yang mempengaruhi ekspresi mRNA HIF1A melalui jalur mTOR. Protein PTEN berfungsi menghambat aktivitas protein mTOR, namun pada kasus kanker hilangnya PTEN akan menyebabkan stabilitas mTOR. mTOR adalah protein serin treonin kinase yang memfosforilasi protein ribosom S6 kinase dan EIF-4E binding protein 1 , protein tersebut meningkatkan transkrip mRNA HIF1A. ${ }^{[25]}$ Beberapa mekaisme tersebut mungkin yang menyebabkan ekspresi mRNA HIF1A mengalami upregulasi sebanyak 5,62 kali pada tipe serous. Upregulasi mRNA HIF1A menyebabkan proses translasi mRNA HIF1A dalam sel kanker akan terus berlangsung menghasilkan protein HIF1A yang lebih banyak. Peningkatan protein HIF1A secara teori akan menyebabkan sel kanker semakin progresif.

Hipoksia menjadi peristiwa penting dalam karsinogenesis karena menyebabkan fenotip sel kanker lebih 
agresif dengan meningkatkan proliferasi, invasi, formasi metastasis dan survival yang lebih buruk. ${ }^{[24]}$ Proses translasi mRNA HIF1A akan menghasilkan protein HIF1A. Protein HIF1A merupakan faktor transkripsi dari beberapa onkogen dan berperan sebagai protein kunci survival selular dibawah kondisi hipoksia dan berhubungan dengan progresi tumor dan metastasis sel kanker. Pada kondisi hipoksia HIF1A stabil dan akan melakukan heterodimer dengan sub unit HIF1B untuk membentuk komplek HIF1 yang mengaktifkan transkripsi gen dengan berikatan pada konsesus responsif elemen HIF (HRE) 5'RCGTG3' pada promoter dan enhancer dari target gen antara lain transporter glukosa, enzim glikolitik dan gen yang terlibat dalam glukoneogenesis, metabolisme fosfat energi tinggi, growth faktor, eritropoesis, metabolisme hemoglobin, gen yang terlibat dalam progresi tumor, metabolisme energi, survival sel, proliferasi, adhesi, angiogenesis dan motilitas. ${ }^{24]}$ Gen-gen tersebut diantaranya erythropoietin, transferrin, endothelin-1, inducible nitric oxide synthetase, heme oxygenase 1,VEGF, insulin-like growth factor-2, insulin-like growth factor binding proteins 2 dan 3 , glucose transporter dan beberapa enzim glikolitik. ${ }^{[25]}$

Kestabilan mRNA HIF1A di dalam plasma darah kanker ovarium telah terbukti dapat dianalisis secara kuantitatif. Sampel yang memiliki ekspresi mRNA HIF1A yang rendah diprediksi merupakan tipe mucinous, sedangkan sampel yang memiliki ekspresi mRNA HIF1A yang tinggi diprediksi merupakan tipe serous. Dengan diketahuinya perbedaan ekspresi mRNA HIF1A plasma kanker ovarium tipe mucinous dan serous, keduanya berpotensi sebagai kandidat biomarker progesifitas kanker ovarium dengan penggunaan sampel dari plasma. mRNA HIF1A dapat dijadikan pertimbangan sebagai kandidat biomarker kanker ovarium.

\section{Kesimpulan}

Terdapat perbedaan signifikan ekspresi mRNA HIF1A pada plasma darah kanker ovarium tipe mucinous dibandingkan dengan tipe serous ( $p$ value $=0,018$ ). Ekspresi mRNA HIF1A pada plasma kanker ovarium tipe serous lebih tinggi 5,62 kali lipat dibandingkan pada tipe mucinous.

\section{REFERENSI}

1. Ahmedin, J. Siegel, R. Xu, J. and Ward, E. 2018. Cancer Statistics. CA Cancer Clin. 60:277-300.

2. Ferlay, J. Soerjomataram, I. Ervik, M. Dikshit, R. Eser, S.C. Mathers, M. Rebelo, M. Parkin, D.M. Forman, D. and Bray, F. 2012. Estimated cancer incidence, mortality and prevalence worldwide in 2018. Globocan. ARC Cancer Base. Diakses dari http://www.iarc.fr/en/publications/ereso urces /cancerbases/.

3. GLOBOCAN, 2012. Estimated cancer incidence, mortality, and prevalence worldwide in 2018. Diakses dari http://globocan.iarc.fr/Pages/online.asp $\mathrm{x}$

4. Liu, B.Y. 2012a. microRNA 155 is downregulated in gastric cancer cells and involved in cell metastasis. Oncol Rep. 1-6.

5. American Cancer Society. Global Cancer Fact \& Figures (2nd Edition). 2011. American Cancer Society. Atlanta GA. USA.

6. Nguyen, L. Cardenas, G. Segundo, J. Gordon, P. Curtin, C. Momeni, M. Chuang, L. and Fishman, D. 2013. Biomarkers for early detection of ovarian cancer. Women's Health. 9(2):171-187.

7. Babar, I.A.J. Czocor, A. Steinmetz, J. B. Weidhaas, P.M. Glazer, and Slack, F.J. 2011. Inhibition of hypoxia- 
induced miR-155 radiosensitizes hypoxic lung cancer cells. Cancer Biology \& Therapy. USA. 12(10):908914.

8. Conde, E. Laura, A. Ignacio, B.S. David, S.M. Elia, A.F. Bele'n, P. Edurne, R. Ana, S. Carlos, J. Angel, O. Manuel, L.C. Luis-del, P. Manuel, O. de, L. Fernando, L. Rafael, S. Jose, A.S. Tomero, and Marı'a L.G.B. 2012. Hypoxia inducible factor 1-alpha (HIF-1 Alpha) is induced during reperfusion after renal ischemia and is critical for proximal tubule cell survival. Plos One. 7(3):33258.

9. Becker, C. A. Hammerle-Fickinger, I. Riedmaier, M.W. Pfaffl. 2010. mRNA and microRNA quality control for RTqPCR analysis. Methods 50: 237-243.

10. George, G.P. and Mittal, R.D. 2010. microRNAs: Potential biomarker in cancer. Clin Biochem. 1:4-14.

11. Ren, Y. Gao, J. Liu, J.Q. Wang, X.W. $\mathrm{Gu}$, J. Huang, $\mathrm{H}$. Gong, $\mathrm{Y}$. and $\mathrm{Li}, \mathrm{Z}$. 2012. Differential signature of fecal microRNAs in patients with pancreatic cancer.

12. Wang and Chen. 2014. Circulating miRNAs in cancer: from detection to Therapy. Journal of Hematology \& Oncology. 7:86.

13. Falcone, G. Felsani, A. and D’Agnano, I. 2015. Signaling by exosomal microRNAs in cancer. Journal of Experimental \& Clinical Cancer Research. 34(32):1-10.

14. Nakamura, K. Sawada, K. Yoshimura, A. Kinose, Y. Nakatsuka, E. and Kimura, T. 2016. Clinical relevance of circulating cell-free microRNAs in ovarian cancer. Molecular Cancer. 15(48):1-10.

15. Cheng, G. 2015. Circulating miRNAs: Roles in cancer diagnosis, prognosis and therapy. Adv Drug Del Rev. (81):75-93.

16. Zheng, S.R. Gui, L.G. Wei, Z. Guan, L.H. Xiao, Q. Jin, Z. Qi, D.H. Jie, Y. and Xiao, H.Z. 2012. Clinical significance of miR-155 expression in breast cancer and effects of miR-155 ASO on cell viability and apoptosis. Oncol Rep. 27:1149-1155.

17. Li, C. Nie, H. Wang, M. Sui, L. Li, J. Yui, Y. Yan, M. Qu, Q. Zhu, Z. and Liu, B. 2012. microRNA 155 is downregulated in gastric cancer cells and involved in cell metastasis. Oncol Rep 27:1960-1966.

18. Qin, W. Ren, Q. Liu, T. and Huang, Y. 2013. MicroRNA-155 is a novel uppressor of ovarian cancer-initiating cells that targets CLDN1. FEBS Letters. 587(9):1434-1439.

19. Davis, B.N., Hilyard, A.C., Lagna, G., Hata, A., 2008. SMAD proteins control DROSHA-mediated microRNA maturation. Nature. 454:56-61.

20. Melo, S.A., Moutinho, C., Ropero, S., Calin, G.A., Rossi, S., Spizzo, R., Fernandez, A.F., Davalos, V., Villanueva, A., Montoya, G., Yamamoto, H., Schwartz Jr., S., Esteller, M., 2010. A genetic defect in exportin-5 traps precursor microRNAs in the nucleus of cancer cells. Cancer Cell. 18:303-315.

21. Newman, M.A., Hammond, S.M., 2010. Emerging paradigms of regulated microRNA processing. Genes Dev. 24: 1086-1092.

22. Warner, D.R., Bhattacherjee, V., Yin, X., Singh, S., Mukhopadhyay, P., Pisano, M.M., Greene, R.M., 2004. Functional interaction between Smad, CREB binding protein, and p68 RNA helicase. Biochem. Biophys. Res. Commun. 324: 70-76.

23. Jansson, M.D. and A. H. Lund. 2012. MicroRNA and cancer. Molecular Oncology 6: 590-610.

24. Laura, M.S. Seeber, A. Horrée, N.A. Marc, A.G.G. Vooijs, A. Peter, M. Heintz, Wall, E.V. D. René, H.M. Verheijen, P. J. and Diest, V. 2011. The role of hypoxia inducible factor1alpha in gynecological cancer. Critical Rev in Oncol/Hematol. (78):173-184.

25. Semenza, G.L. 2010. HIF-1: upstream and downstream of cancer metabolism. Curr Opin Genet Dev. 20(1): 51. 